Monika Borowiec, SŁawomir Dorocki

Uniwersytet Pedagogiczny im. Komisji Edukacji Narodowej w Krakowie

BARTOSZ JENNER

Uniwersytet Jagielloński

\title{
Wpływ zasobów kapitału ludzkiego na kształtowanie społeczeństwa informacyjnego i innowacyjności struktur przemysłowych
}

$\mathrm{W}$ procesie przechodzenia $\mathrm{z}$ industrialnej fazy rozwoju cywilizacyjnego do fazy informacyjnej w zasadniczym stopniu ulega zmianie baza ekonomiczna różnej skali układów przestrzennych. Efektem tego jest zmiana struktury rynku pracy. Zmniejsza się udział pracujących w tradycyjnych sektorach przemysłowych na rzecz pracujących w nowych sektorach związanych z przemysłem informatycznym, na co wskazuje m.in. liczba zatrudnionych w sektorach wysokich technologii, zarówno przemysłu jak i usług. Powszechnie przyjmuje się, że w rozwoju społeczeństwa informacyjnego wiedza i informacja odgrywają podstawową rolę w działalności społeczno-ekonomicznej, zwiększa się znaczenie specjalistów i naukowców w strukturze zawodowej ludności oraz dominacja sektora usług w gospodarce, wzrasta znaczenie wiedzy teoretycznej jako źródła innowacji, a także ukierunkowanie gospodarki na rozwój określonych dziedzin techniki.

Zmiany strukturalne - jak określa Okoń-Horodyńska (2000) - nie są osiagane przez prosty trans-
fer innowacji (np. nowej technologii) pomiędzy różnymi krajami. Rzeczywiste źródła restruk-
turyzacji mają korzenie w kompetencjach (wiedzy, umiejętnościach, wartościach, postawach)
i kreatywności, wzmacnianych poprzez aktywność zespołową i sprawną komunikację wewnętrz-
ną, wspieranych od strony organizacyjnej i informatycznej, znajdujących potwierdzenie w przed-
siębiorczości innowacyjnej, podejmowanej coraz częściej w ramach struktur sieciowych (Bal-
-Woźniak 2009, s. 56).

Przyjmuje się, że zasoby niezbędne do kształtowania infrastruktury systemów innowacyjnych są wynikiem długotrwałego rozwoju i efektem inwestowania w kapitał ludzki. Gospodarka oparta na wiedzy funkcjonuje w oparciu o wykorzystanie zasobów wiedzy oraz rozwoju technologii umożliwiającej szybki i tani dostęp do informacji, a podstawą jej rozwoju jest zdolność do generowania i dyfuzji innowacji, które prowadzą do modernizacji, wzrostu produktywności i konkurencyjności gospodarki (Skrzypek 2007; Babiak 2008; Chojnicki, Czyż 2008; Goldberg, Goddard, Kuriakose 2008; Markowski 2008). Nauka i technologia stanowią kluczowe ogniwo w rozwoju społeczno-gospodarczym układów regionalnych, a ich konkurencyjność zależy od sprawności funkcjonowania regionalnych systemów innowacji (Reichel 2006). Na jakość krajowych i regionalnych systemów innowacyjnych 
w dużym stopniu wpływa poziom wykształcenia społeczeństwa oraz rozwój i jakość funkcjonowania jednostek naukowych i badawczo-rozwojowych.

W niniejszych rozważaniach podjęto analizę zróżnicowania i zmian wybranych wskaźników dotyczących potencjału edukacyjnego i jakości kapitału ludzkiego w przestrzeni europejskiej, które warunkują rozwój społeczeństwa informacyjnego i wzrost innowacyjności gospodarki.

Cechy odnoszące się do potencjału edukacyjnego i jakości kapitału ludzkiego to: udział osób z wyższym wykształceniem w ogólnej liczbie pracujących, udział studentów w ogólnej liczbie ludności, udział wydatków na działalność B+R w szkolnictwie wyższym w PKB, zasoby ludzkie dla nauki i techniki (HRST - Human Resources for Science and Technology). Cechy odnoszące się do innowacyjności przemysłu to udział pracujących w przemyśle wyższych i średnich technologii w ogólnej liczbie pracujących, udział pracujących w usługach „wiedzochłonnych” w ogólnej liczbie pracujących, udział personelu sektora B+R w ogólnej liczbie pracujących oraz wskaźnik regionalnej innowacyjności (Regional Innovation Scoreboard). Ze względu na dostępność wskaźników empirycznych analizę przeprowadzono dla 19 państw Unii Europejskiej (bez Estonii, Łotwy, Litwy, Malty, Cypru, Bułgarii, Rumunii i Słowenii), a także dla krajów spoza Unii Europejskiej - Szwajcarii i Norwegii.

W niniejszym artykule przy pomocy wartości mierników syntetycznych odnoszących się do zróżnicowania potencjału intelektualnego i zaawansowania technologicznego gospodarki analizowanych układów przestrzennych (regiony NUTS 2 i NUTS 1) podjęta została próba określenia stopnia zależności pomiędzy wybranymi cechami oraz dynamiki ich rozwoju i korelacji w czasie. W badaniach uwzględniony został także wpływ poszczególnych wskaźników empirycznych na wartość mierników syntetycznych. Pozwoliło to na dokonanie pewnej hierarchii przestrzeni europejskiej w zakresie analizowanych cech i wartości syntetycznych określających zróżnicowanie jakości zasobów intelektualnych i innowacyjności gospodarki.

Poszczególne wskaźniki wykazują różny stopień przestrzennego zróżnicowania, na co wskazuje współczynnik zmienności odchylenia standardowego wahający się od 27,90\% dla wskaźnika udział pracujących w usługach ,wiedzochłonnych” w ogólnej liczbie pracujących do 94,14\% dla wskaźnika udział wydatków na działalność B+R w szkolnictwie wyższym w PKB.

Pierwszy wskaźnik odnoszący się do innowacyjności przemysłu - udział pracujących w przemyśle wysokich i średnich technologii w ogólnej liczbie pracujących - w 2006 r. waha się od 17,7\% w Baden-Württemberg w Niemczech do 0,69\% w Canarias w Hiszpanii (ryc. 1).

Najwyższym udziałem pracujących w przemyśle wysokich i średnich technologii w ogólnej liczbie pracujących (powyżej 10\%) odznacza się 21 regionów występujących na obszarze siedmiu państw, z których najwięcej występuje w Czechach, Niemczech i we Włoszech (po 6 regionów), a po jednym we Francji, Słowacji i Hiszpanii. Natomiast najniższy udział pracujących w przemyśle wysokich i średnich technologii w ogólnej liczbie pracujących (poniżej 2\%) występuje w dziesięciu regionach: czterech w Hiszpanii, trzech w Grecji, dwóch we Włoszech i Luksemburgu.

Kolejny wskaźnik - udział zatrudnionych w „wiedzochłonnych” usługach w ogólnej liczbie pracujących - w 2006 r. waha się od 56,4\% w Sztokholmie do 18,3\% w Centro w Portugalii (ryc. 2). Najwyższym udziałem zatrudnionych w ,wiedzochłonnych” usługach w ogólnej liczbie pracujących (powyżej 45\%) charakteryzuje się 18 regionów 
poza wspomnianym Sztokholmem: sześć regionów w Szwecji, cztery w Norwegii, po dwa w Szwajcarii i Wielkiej Brytanii, po jednym w Belgii, Niemczech, Finlandii, Francji i Holandii. Najmniejszym udziałem zatrudnionych w „wiedzochłonnych” usługach w ogólnej liczbie pracujących odznacza się osiem regionów: w Grecji, Polsce i Portugalii (po 2) oraz po jednym na Węgrzech i w Republice Czeskiej.

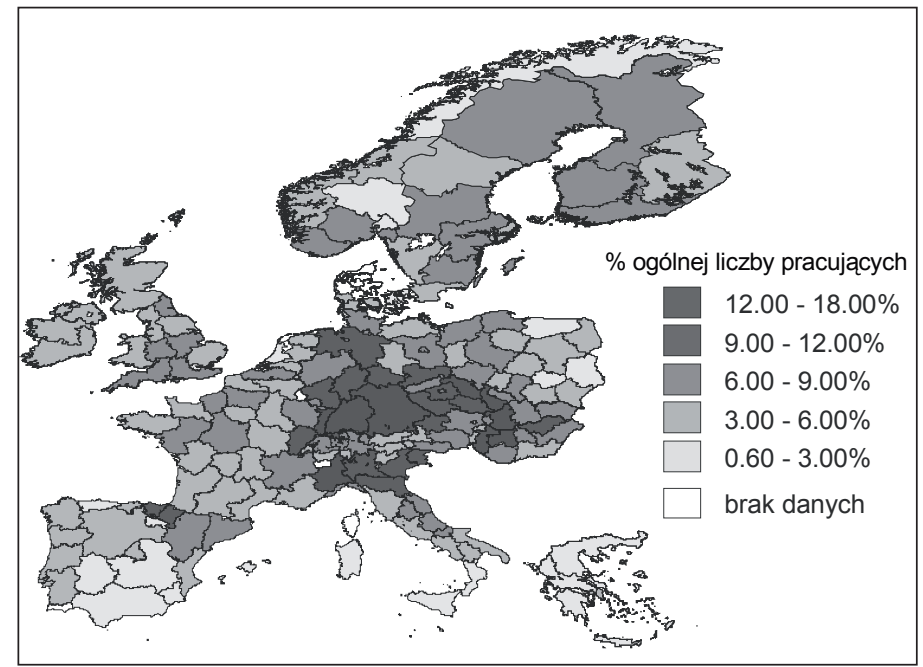

Ryc. 1. Udział pracujących w przemyśle wysokich i średnich technologii w ogólnej liczbie pracujących w 2006 r.

Źródło: opracowanie własne na podstawie Eurostatu

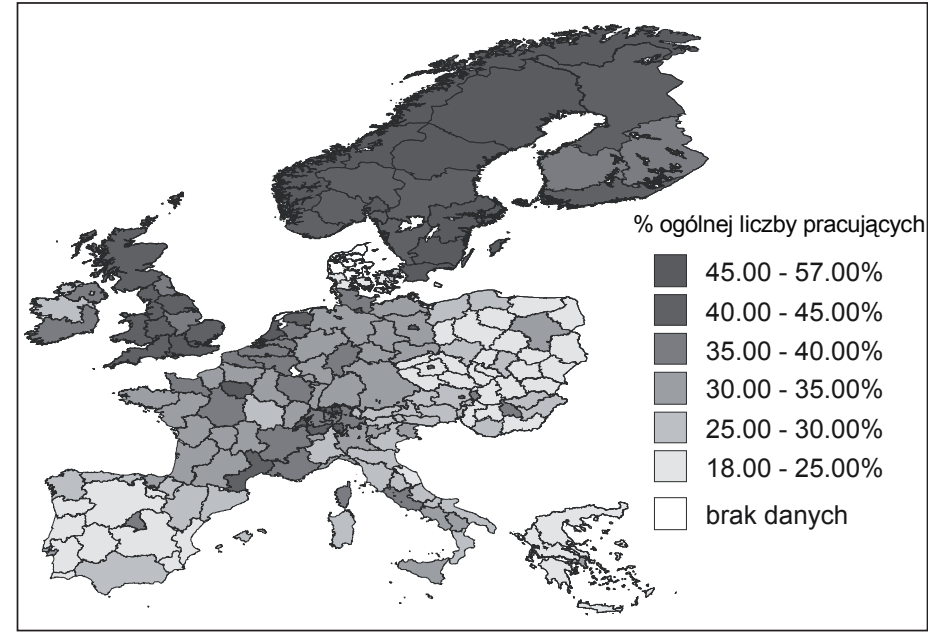

Ryc. 2. Udział zatrudnionych w ,wiedzochłonnych” usługach w ogólnej liczbie pracujących w 2006 r.

Źródło: opracowanie własne na podstawie Eurostatu 
Następny wskaźnik - udział personelu sektora B+R w ogólnej liczbie pracujących w 2006 r. waha się od 4,01\% w Trøndelag w Norwegii do 0,22\% w Severozapad w Republice Czeskiej (ryc. 3).

Najwyższym udziałem personelu sektora $\mathrm{B}+\mathrm{R}$ w ogólnej liczbie pracujących (ponad $3 \%$, poza regionem Trøndelag, charakteryzuje się tylko pięć regionów: dwa w Finlandii i po jednym w Norwegii (Oslo), Austrii (Wiedeń) i Francji (Île de France). Również wysoki udział personelu sektora $\mathrm{B}+\mathrm{R}$ w ogólnej liczbie pracujących (powyżej 2\%) występuje w 10 regionach na obszarze siedmiu państw: w trzech regionach w Niemczech, a po jednym w Finlandii, Francji, Norwegii oraz w stolicach Pradze, Bratysławie i Madrycie. Łącznie zatem udział personelu sektora $\mathrm{B}+\mathrm{R}$ w ogólnej liczbie pracujących wynoszący powyżej 2\% występuje tylko w 15 regionach na obszarze ośmiu państw. Najmniejszym udziałem personelu sektora $\mathrm{B}+\mathrm{R}$ w ogólnej liczbie pracujących (poniżej 0,5\%) charakteryzuje się 11 regionów, z czego trzy w Polsce (województwo podkarpackie, lubuskie, świętokrzyskie), dwa we Włoszech, Francja, Austria, Portugalia, Hiszpania, Finlandia i Republika Czeska.

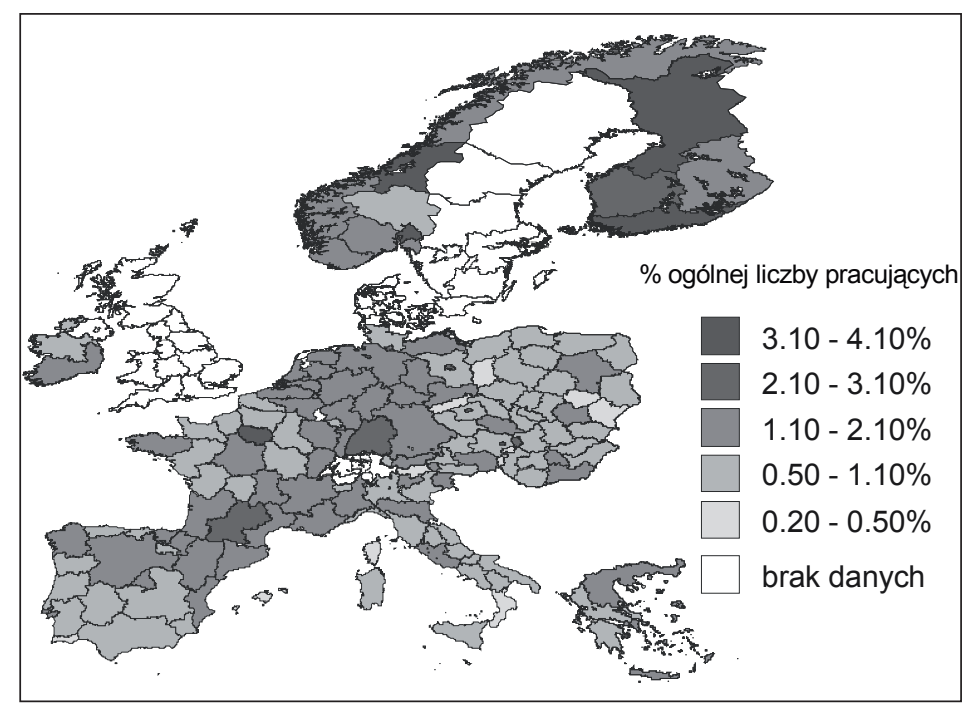

Ryc. 3. Udział personelu sektora B+R w ogólnej liczbie pracujących w 2006 r.

Źródło: opracowanie własne na podstawie Eurostatu

Wskaźnik regionalnej innowacyjności (Regional Innovation Scoreboard) w 2006 r. waha się od 0,9 w Sztokholmie do 0,1 w Nisia Aigaiou, Kriti w Grecji (ryc. 4). Najwyższymi wartościami poza Sztokholmem (powyżej 0,7) odznacza się osiem regionów, z tego trzy znajdujące się w Szwecji, dwa w Niemczech i po jednym w Wielkiej Brytanii, Francji i Finlandii. Najniższymi wartościami wskaźnika regionalnej innowacyjności (poniżej 0,2) charakteryzuje się 10 regionów: po trzy w Hiszpanii i Grecji, dwa w Portugalii, po jednym w Republice Czeskiej i Słowacji.

Celem określenia stopnia zróżnicowania innowacyjności regionów (pod względem zatrudnienia) określono miernik syntetyczny w oparciu o cztery przyjęte i przedstawione powyżej cechy ${ }^{1}$. W świetle jego wartości przestrzeń europejska charakteryzuje się bardzo

\footnotetext{
1 Miernik syntetyczny obliczono według: Zioło (1985).
} 
dużym zróżnicowaniem, czego wyrazem jest wartość miernika syntetycznego wahająca się od 1,15 w Baden-Württemberg w Niemczech do 0,19 w województwie świętokrzyskim w Polsce (ryc. 5).

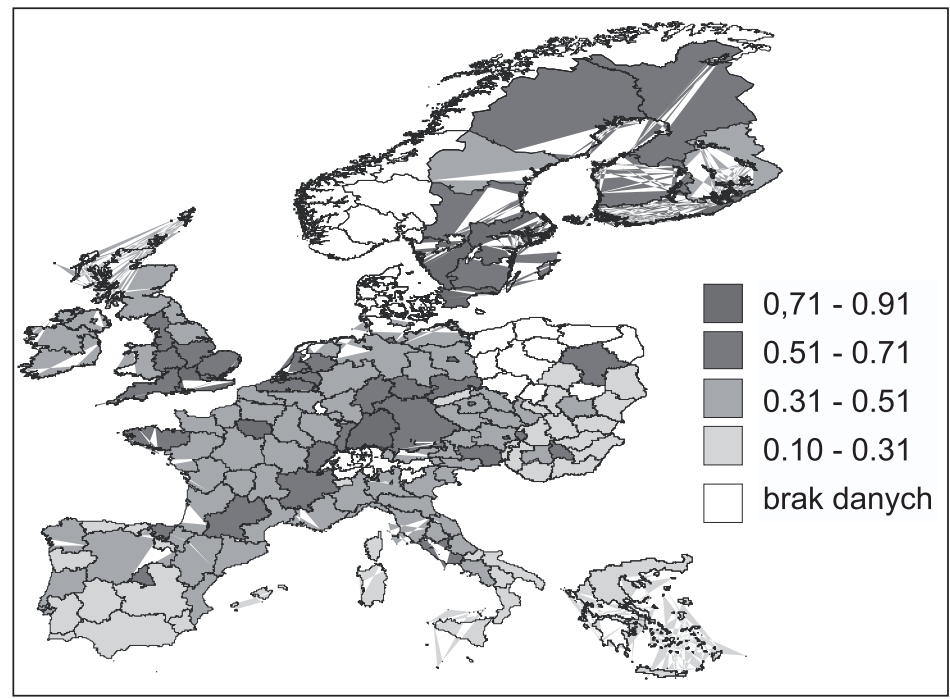

Ryc. 4. Wskaźnik regionalnej innowacyjności w 2006 r.

Źródło: opracowanie własne na podstawie Eurostatu

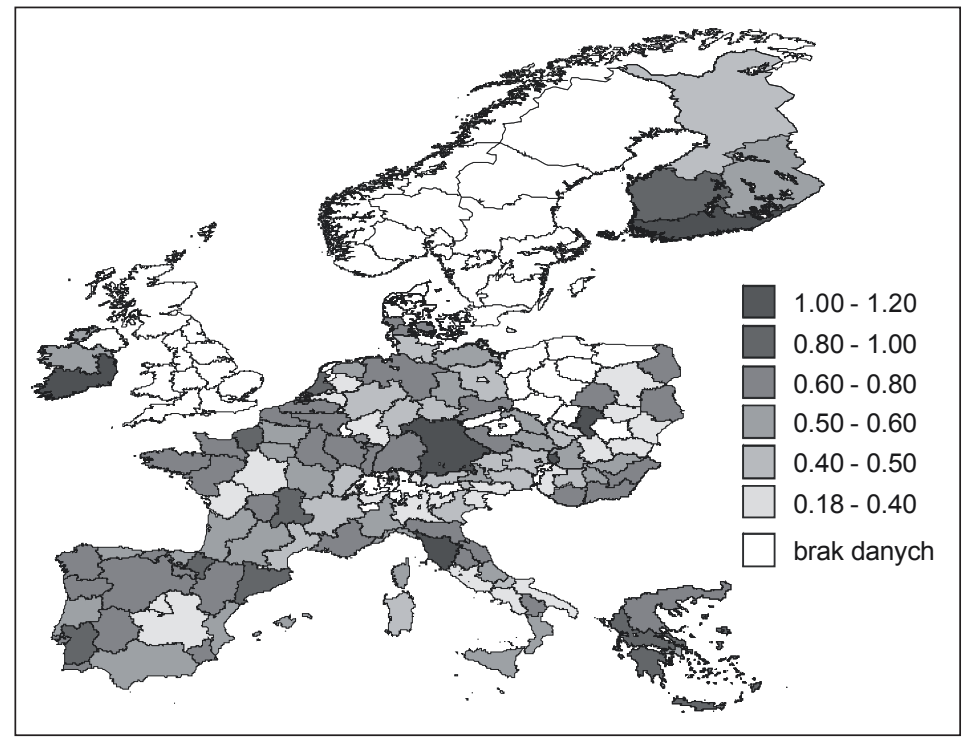

Ryc. 5. Miernik syntetyczny innowacyjności regionów w 2006 r. 
Najwyższymi wartościami miernika syntetycznego (powyżej 0,70) charakteryzuje się 34 regionów, co stanowi 19,9\% ogólnej ich liczby (181) i znajdują się one na obszarze 13 państw. Najwięcej z nich występuje w Niemczech (11), Francji (5) i we Włoszech (4), w Finlandii i Hiszpanii (po 3), Belgii, Austrii (po 2) oraz w Republice Czeskiej, Holandii, Słowacji i na Węgrzech, (po 1). Natomiast najniższymi wartościami miernika syntetycznego (poniżej 0,40) odznacza się 40 regionów, co stanowi 22,1\% ogólnej ich liczby i znajdują się one na obszarze 11 państw. Największa ich liczba występuje na obszarze Polski (10), następnie w Szwajcarii (6), Portugalii (4), we Włoszech i Hiszpanii (po 5), w Grecji i Danii (po 3) oraz w Republice Czeskiej, Finlandii, Francji i Norwegii (po 1).

Analiza ta wskazuje zatem wyraźnie na znaczną polaryzację w zakresie struktury zatrudnienia nie tylko w skali układów krajowych, ale również regionalnych, zwłaszcza we Włoszech i Hiszpanii, na których obszarze znajdują się regiony zarówno o najwyższych, jak i najniższych wartościach miernika syntetycznego.

Kolejna przyjęta do analizy grupa wskaźników odnosi się do jakości kapitału ludzkiego, który w świetle przyjętych cech odznacza się znacznym zróżnicowaniem w układach przestrzennych Europy (por. Borowiec 2008). Pierwszy ze wskaźników określających jakość kapitału ludzkiego - udział ludności z wyższym wykształceniem w ogólnej liczbie pracujących - w 2006 r. waha się od 53,6\% w Luksemburgu do 8,5\% w Severozapad w Republice Czeskiej (ryc. 6). Najwyższym udziałem ludności z wyższym wykształceniem w ogólnej liczbie pracujących (powyżej 40\%) poza Luksemburgiem odznacza się sześć regionów znajdujących się na obszarze: Francji, Wielkiej Brytanii, Norwegii i Belgii, gdzie dotyczy to stolic tych państw, oraz dwa regiony Hiszpanii (Pais Vasco i Navarra).

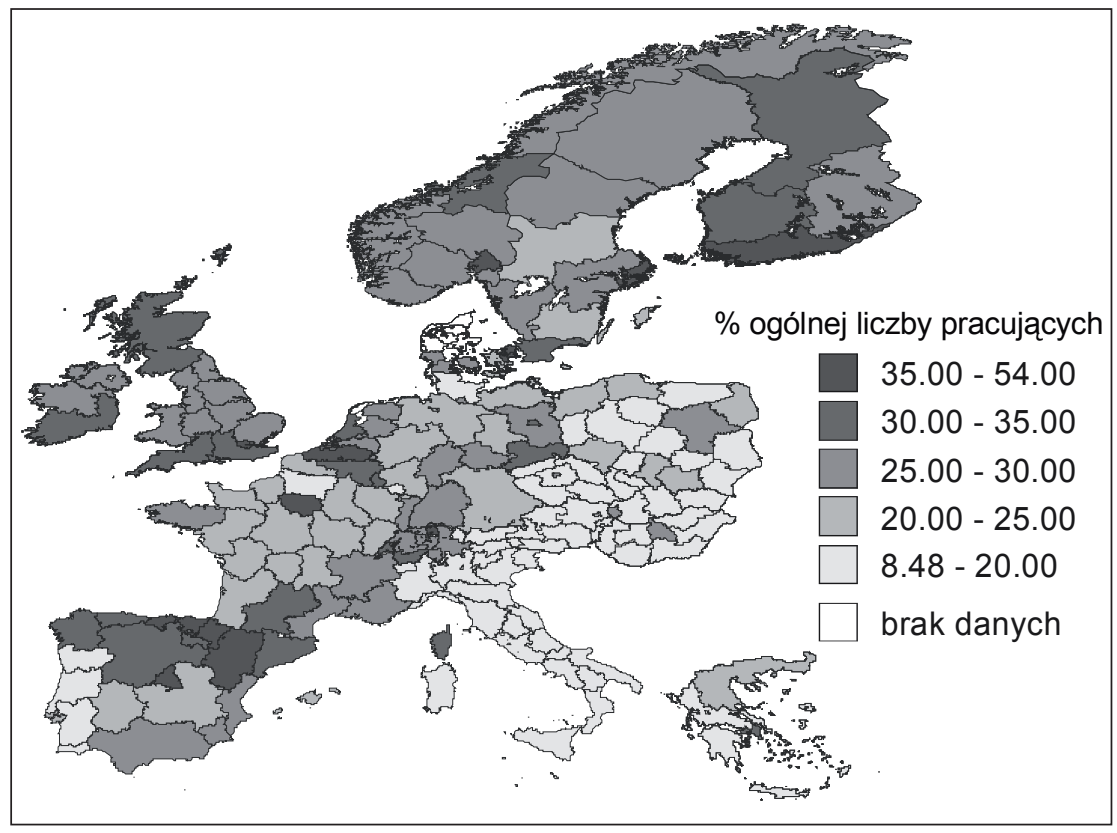

Ryc. 6. Udział ludności z wyższym wykształceniem w ogólnej liczbie pracujących w 2006 r.

Źródło: opracowanie własne na podstawie Eurostatu 
Od 30-40\% ludności z wyższym wykształceniem w ogólnej liczbie pracujących występuje w 29 regionach, głównie na obszarze Hiszpanii (8 regionów), Wielkiej Brytanii i Finlandii (po 3), Niemczech, Belgii, Szwajcarii, Francji, Szwecji (po 2) oraz po jednym w Danii, Grecji, Holandii, Norwegii, Irlandii.

Najniższym udziałem poniżej 15\% ludności z wyższym wykształceniem w ogólnej liczbie pracujących charakteryzuje się 27 regionów, z których aż 11 znajduje się we Włoszech, $6 \mathrm{w}$ Czechach, $4 \mathrm{w}$ Portugalii, 3 na Słowacji, po jednym w Austrii (Tyrol), na Węgrzech (Nyugat-Dunantul/Western Transdanubia) w Polsce (województwo kujawsko-pomorskie).

Następny wskaźnik - udział studentów w ogólnej liczbie ludności - w 2006 r. waha się od 13,2 w Oevre Norrland w Szwecji do 0,3\% w Stredni Cechy w Republice Czeskiej (ryc. 7).

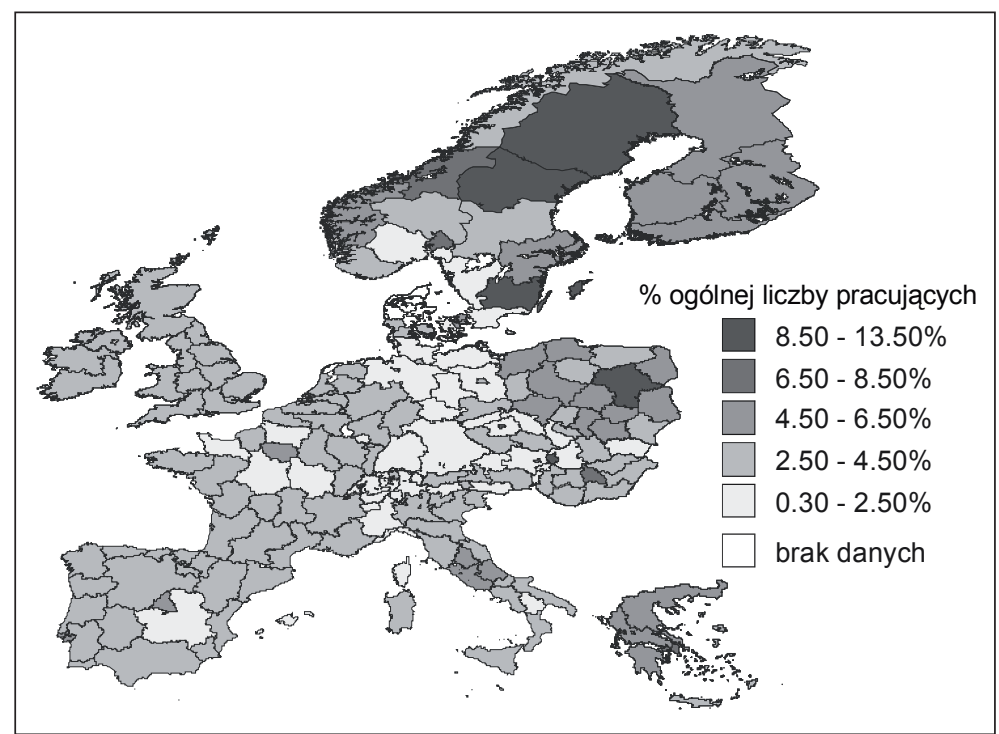

Ryc. 7. Udział studentów w ogólnej liczbie ludności w 2006 r.

Źródło: opracowanie własne na podstawie Eurostatu

Wysokim powyżej 8,5\% udziałem studentów w ogólnej liczbie ludności odznacza się także region Bratysławy, Mellersta Norrland i Smaaland Med Oerna w Szwecji oraz województwo mazowieckie w Polsce. Nieco mniejszym udziałem studentów w ogólnej liczbie ludności (od 6,5\% do 8,5\%) charakteryzuje się sześć regionów: dwa w Norwegii, po jednym w Belgii, Austrii, Grecji i na Węgrzech. Łącznie tych dwanaście regionów, w których udział studentów w ogólnej liczbie ludności jest wyższy od 6,5\%, jest skupionych na obszarze ośmiu państw. Najmniejszy udział studentów w ogólnej liczbie ludności (poniżej 2,5\%) występuje w 44 regionach znajdujących się na obszarze: Niemiec (9), Szwajcarii (6), Austrii, Francji, Włoch, (po 5), Czech (4), Hiszpanii, Szwecji, Słowenii (po 2) oraz po jednym w Danii, Finlandii, Norwegii i w Luksemburgu.

Zróżnicowanie wydatków na działalność $\mathrm{B}+\mathrm{R}$ w szkolnictwie wyższym w PKB w 2006 r. waha się od 3,6\% w Mellersta Norrland w Szwecji do 0,01\% w Severozapad w Czechach (ryc. 8). Najwyższym udziałem wydatków na działalność B+R w szkolnictwie 
wyższym w PKB (powyżej 1\%) charakteryzują się zaledwie cztery regiony, z czego dwa również w Szwecji, Trøndelag w Norwegii i Wiedeń w Austrii. Najniższym udziałem wydatków na działalność B+R w szkolnictwie wyższym w PKB (poniżej 0,2\%) odznacza się aż 41 regionów występujących głównie na obszarze Polski (10), Czech i Hiszpanii (po 5), Słowacji (4), Niemiec, Francji, Włoszech i Norwegii (po 3).

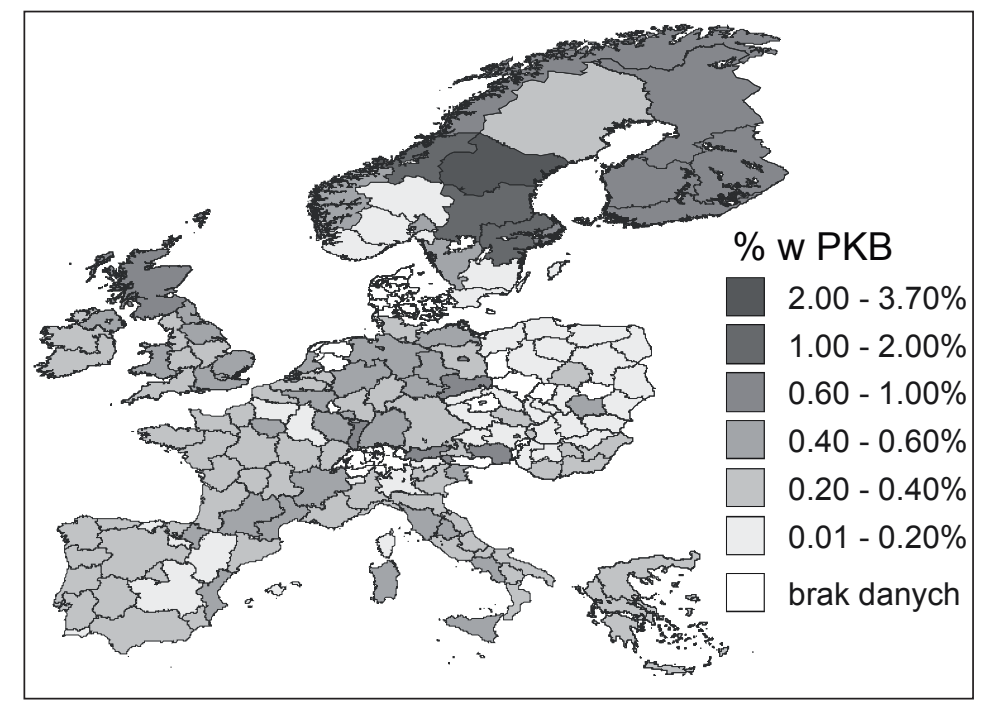

Ryc. 8. Wydatki na działalność B+R w szkolnictwie wyższym w PKB w 2006 r.

Źródło: opracowanie własne na podstawie Eurostatu

Ostatni z tej grupy wskaźnik - zasoby ludzkie dla nauki i techniki (HRST) waha się od 47,1\% w Sztokholmie w Szwecji do 12,5\% w Centro w Portugalii (ryc. 9). Najwyższym powyżej 40\% udziałem charakteryzuje się sześć regionów, poza Szwecją znajdują się one w Danii, Czechach, Francji, Finlandii i Hiszpanii. Powyżej 30\% występuje w 36 regionach Europy, głównie w Holandii, Finlandii, Niemczech, Szwecji, Wielkiej Brytanii. Najmniejszy udział HRST (poniżej 20\%) ma się 37 regionów, głównie na obszarze Węgrzech, Włoch, Polski, Portugalii, Słowacji i Grecji.

W oparciu o przedstawione powyżej cechy obliczono syntetyczny miernik kapitału ludzkiego. Miernik ten waha się od 0,20 w Ost for Storebaelt w Danii do 2,10 w Mellersta Norrland w Szwecji (ryc. 10).

Najwyższymi wartościami miernika syntetycznego (powyżej 0,70) charakteryzuje się 31 regionów, co stanowi 17,1\% ogólnej ich liczby i znajdują się one na obszarze 13 państw. Najwięcej z nich znajduje się w Szwecji (6), w Finlandii (4), Austrii, Francji, Hiszpanii i Niemczech (po 3), w Wielkiej Brytanii i Norwegii (po 2) oraz w Belgii, Holandii, Polsce, Republice Czeskiej, Słowacji (po 1).

Natomiast najniższymi wartościami miernika syntetycznego (poniżej 0,40) odznacza się 39 regionów, stanowiących 21,5\% ogólnej ich liczby i znajdujących się na obszarze 11 państw. Najwięcej z nich znajduje się w Szwajcarii i Czechach (6), Austrii (5), Polsce, Portugalii i we Włoszech (po 4), na Słowacji (3), w Norwegii, Danii, na Węgrzech (po 2) oraz we Francji (1). 


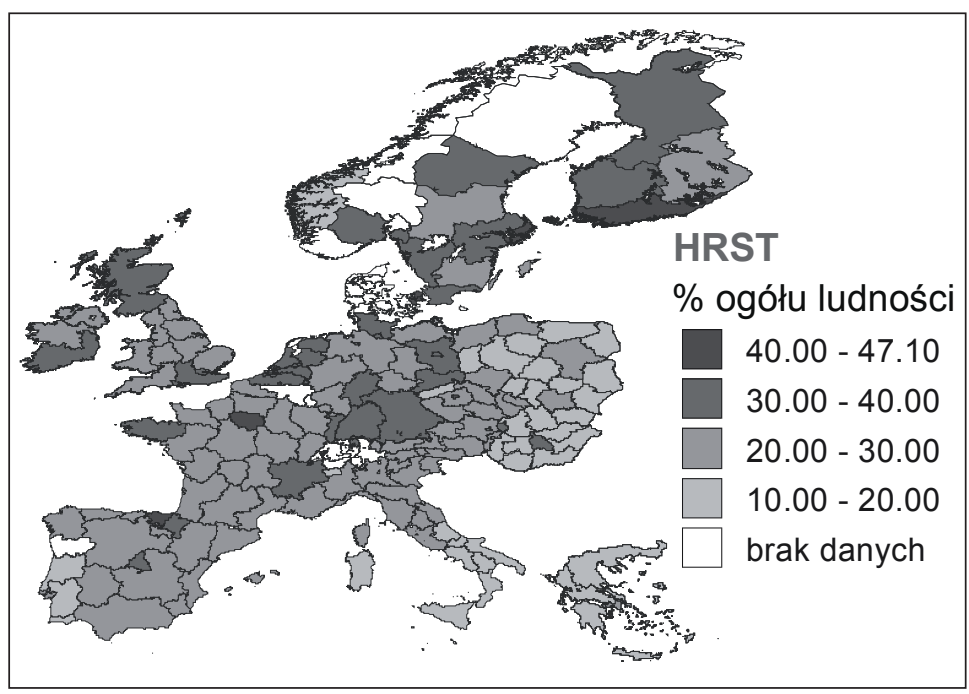

Ryc. 9. Zasoby ludzkie dla nauki i techniki w $2006 \mathrm{r}$.

Źródło: opracowanie własne na podstawie Eurostatu

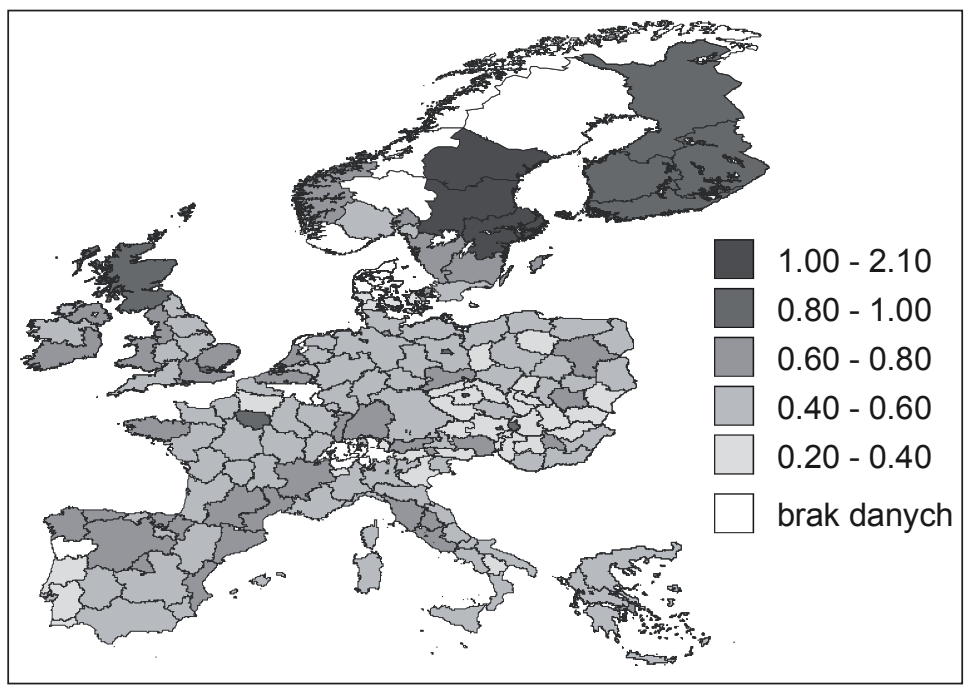

Ryc. 10. Syntetyczny miernik kapitału ludzkiego w 2006 r.

Źródło: opracowanie na podstawie własnych obliczeń

$\mathrm{Na}$ wartość mierników syntetycznych w różnym stopniu wpłynęły przyjęte cechy. Za determinujący wpływ przyjęto ponad 35\% udział danego wskaźnika w strukturze miernika syntetycznego. W strukturze miernika syntetycznego innowacyjności gospodarki wskaźnik udział pracujących w przemyśle wysokich i średnich technologii w ogólnej liczbie pracujących miał największe znacznie dla regionów w Niemczech, Republice Czeskiej, Polsce, na Słowacji, we Włoszech; wskaźnik udział zatrudnionych w „wiedzochłonnych” usługach 
w ogólnej liczbie pracujących największe znacznie odgrywał w regionach we Włoszech i Hiszpanii; a udział personelu sektora $\mathrm{B}+\mathrm{R}$ w ogólnej liczbie pracujących $\mathrm{w}$ regionach Finlandii, Grecji, Francji, Polski, Republiki Czeskiej i Hiszpanii (ryc. 11).

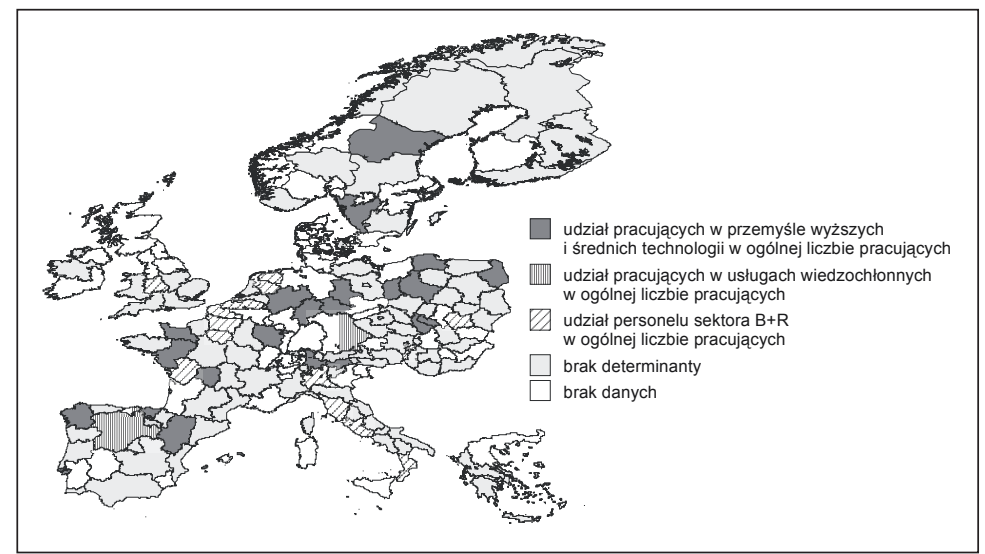

Ryc. 11. Zróżnicowanie struktury miernika syntetycznego innowacyjności gospodarki w $2006 \mathrm{r}$.

Źródło: opracowanie na podstawie własnych obliczeń

W strukturze miernika syntetycznego kapitału ludzkiego wskaźnik zasoby ludzkie dla nauki i techniki (HRST) miał największe znaczenie głównie dla regionów Czech, Niemiec i Austrii; udział pracowników z wyższym wykształceniem miał duże znacznie głównie dla regionów Szwajcarii, Danii, Norwegii, Francji i Hiszpanii; udział wydatków na działalność B+R w szkolnictwie wyższym w PKB największe znaczenie miał dla regionów Finlandii, Szwecji, Włoch, Wielkiej Brytanii, Francji, Austrii; a udział studentów w ogólnej liczbie ludności miał determinujące znaczenie głównie dla regionów Polski, Grecji, Szwecji, Słowacji (ryc. 12).

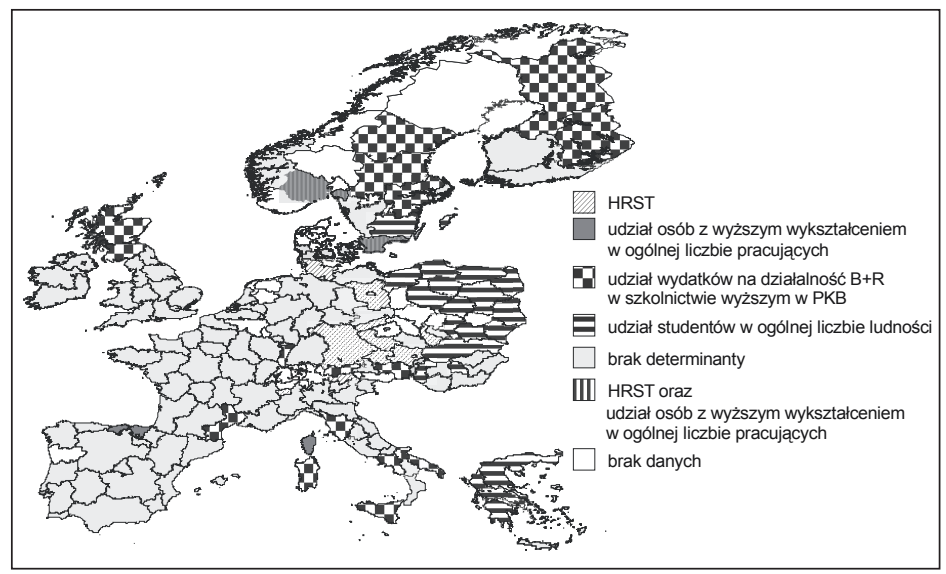

Ryc. 12. Zróżnicowanie struktury miernika syntetycznego kapitału ludzkiego w $2006 \mathrm{r}$.

Źródło: opracowanie na podstawie własnych obliczeń 
Pojawia się pytanie, czy pomiędzy przyjętymi wskaźnikami zaznacza się wzajemna zależność (ryc. 13). Biorąc pod uwagę wartość korelacji kanonicznej wszystkich analizowanych wskaźników zależność jest bardzo duża (R: 0,916; $\mathrm{p}=0,0000)$. Zaznaczyć należy, że tak samo jak w przypadku obliczania mierników syntetycznych ograniczono się jedynie do analizy regionów, dla których były dostępne wszystkie analizowane wskaźniki.

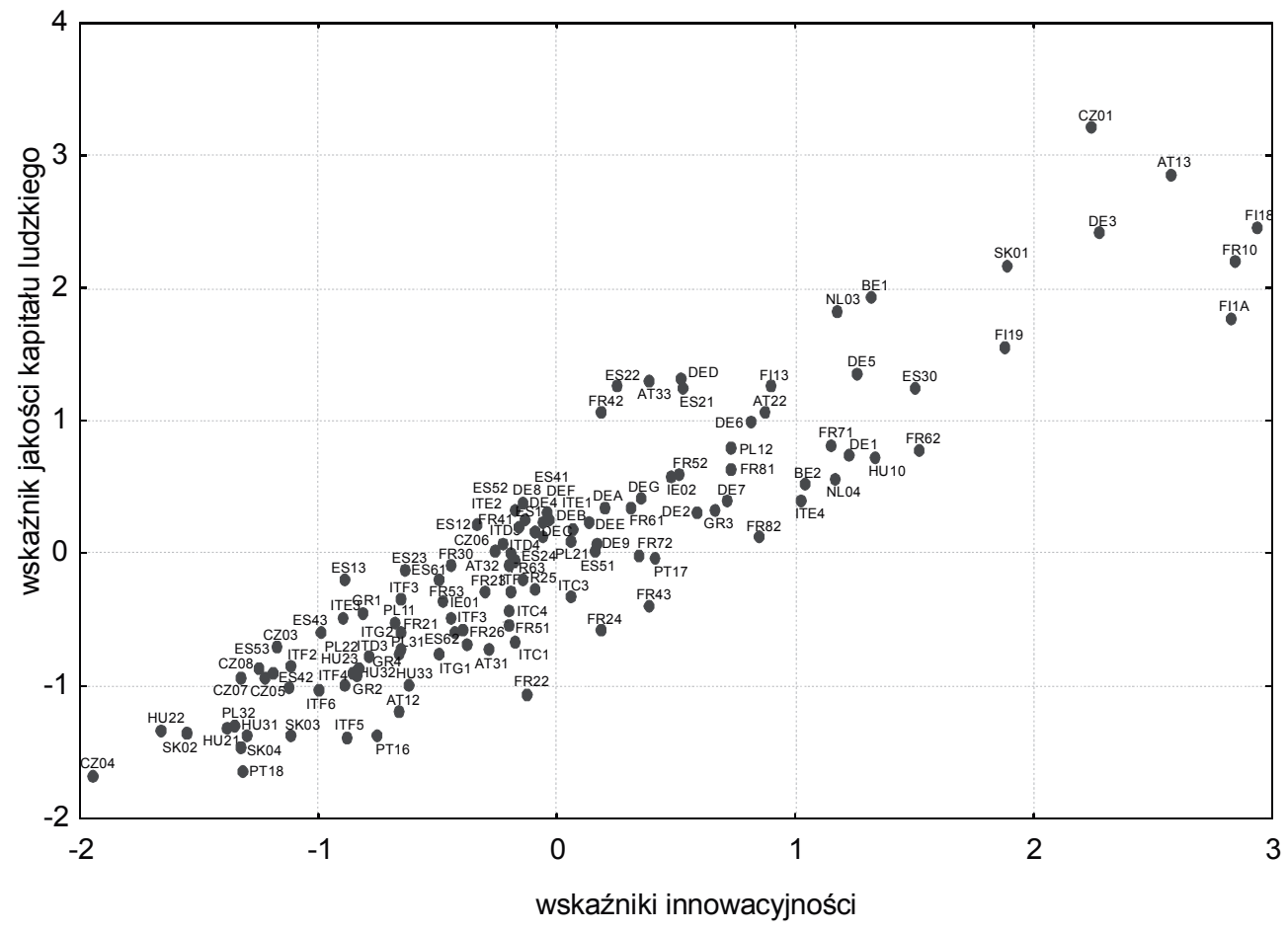

Ryc. 13. Korelacja pomiędzy wskaźnikami innowacyjności a wskaźnikami jakości kapitału ludzkiego w 2006 r.

Źródło: opracowanie na podstawie własnych obliczeń

W grupie wskaźników określających innowacyjność gospodarki największy stopień korelacji zaznacza się pomiędzy wskaźnikiem regionalnej innowacyjności a udziałem personelu sektora $\mathrm{B}+\mathrm{R}$ w ogólnej liczbie pracujących $(0,844)$ i udziałem pracujących w ,wiedzochłonnych" usługach w ogólnej liczbie pracujących $(0,777)$, a także pomiędzy udziałem personelu sektora $\mathrm{B}+\mathrm{R}$ w ogólnej liczbie pracujących a udziałem pracujących w „wiedzochłonnych" usługach w ogólnej liczbie pracujących $(0,707)$. Natomiast w grupie wskaźników odnoszących się do jakości kapitału ludzkiego wyraźny stopień zależności zaznacza się tylko pomiędzy udziałem osób z wyższym wykształceniem w ogólnej liczbie pracujących a zasobami ludzkimi dla nauki i techniki $(0,790)$. Poszczególne cechy wykazują różny stopień wzajemnej zależności. Wyrazem tego jest zróżnicowanie wartości wskaźnika korelacji pomiędzy wszystkimi przyjętymi, które wahają się od -0,081 do 0,807 (tab. 1). Największa zależność w układach regionalnych występuje pomiędzy wskaźnikiem zasoby ludzkie dla nauki i techniki (HRST) a wskaźnikiem regionalnej innowacyjności $(0,807)$, udziałem pracujących w „wiedzochłonnych” usługach w ogólnej liczbie pracujących $(0,737)$ oraz udziałem personelu sektora B+R w ogólnej liczbie pracujących $(0,719)$. 
Tab. 1. Zróżnicowanie korelacji pomiędzy badanymi cechami w $2006 \mathrm{r}$.

\begin{tabular}{|l|c|c|c|c|}
\hline & $\begin{array}{c}\text { Udział osób } \\
\text { z wyższym } \\
\text { wykształceniem } \\
\text { w ogólnej } \\
\text { liczbie pracujących }\end{array}$ & $\begin{array}{c}\text { Udział } \\
\text { studentów } \\
\text { w ogólnej } \\
\text { liczbie } \\
\text { ludności }\end{array}$ & $\begin{array}{c}\text { Udział wydatków } \\
\text { na działalność } \\
\text { B+R } \\
\text { w szkolnictwie } \\
\text { wyższym w PKB }\end{array}$ & $\begin{array}{c}\text { Zasoby ludzkie } \\
\text { dla nauki i techniki } \\
\text { (HRST-Human } \\
\text { Resources } \\
\text { for Science and } \\
\text { Technology) }\end{array}$ \\
\hline $\begin{array}{l}\text { Udział pracujących w przemyśle } \\
\text { wyższych i średnich technologii } \\
\text { w ogólnej liczbie pracujących }\end{array}$ & $-0,203$ & $-0,277$ & $-0,081$ & 0,085 \\
\hline $\begin{array}{l}\text { Udział pracujaccych w usługach } \\
\text { „wiedzochłonnych" w ogólnej } \\
\text { liczbie pracujących }\end{array}$ & 0,539 & 0,319 & 0,507 & 0,737 \\
\hline $\begin{array}{l}\text { Udział personelu sektora B+R } \\
\text { w ogólnej liczbie pracujących }\end{array}$ & 0,589 & 0,565 & 0,659 & 0,719 \\
\hline $\begin{array}{l}\text { Wskaźnik regionalnej innowa- } \\
\text { cyjności (Regional Innovation } \\
\text { Scoreboard) }\end{array}$ & 0,521 & 0,342 & 0,521 & 0,807 \\
\hline
\end{tabular}

Źródło: opracowanie na podstawie własnych obliczeń

Analizując korelację wewnątrzregionalną pomiędzy analizowanymi wskaźnikami w latach 1995-2006 ograniczono się do przypadków, gdzie korelacja była istotna statystycznie, czyli do regionów, gdzie wartość korelacji pomiędzy danymi wskaźnikami była większa lub równa 0,8 (ryc. 13). Najsilniejsza dodatnia zależność zachodzi pomiędzy zmianami wartości wskaźnika udział pracujących w usługach ,wiedzochłonnych” w ogólnej liczbie pracujących a wskaźnikami udział osób z wyższym wykształceniem w ogólnej liczbie pracujących oraz udział studentów w ogólnej liczbie ludności i udział pracujących w usługach „wiedzochłonnych" w ogólnej liczbie pracujących. Korelacja pomiędzy udziałem pracujących w usługach „wiedzochłonnych” w ogólnej liczbie pracujących a udziałem osób z wyższym wykształceniem w ogólnej liczbie pracujących najwyraźniej zaznacza się regionach Wielkiej Brytanii, Irlandii, Finlandii, Słowacji, Hiszpanii, Portugalii, Grecji i we Włoszech.

Natomiast wyraźna odwrotna tendencja zachodzi pomiędzy udziałem osób z wyższym wykształceniem w ogólnej liczbie pracujących a udziałem pracujących w przemyśle wysokich i średnich technologii w ogólnej liczbie pracujących. Najwyższy ujemny stopień korelacji zaznacza się w regionach Wielkiej Brytanii, Finlandii i Belgii, a w większości regionów brak zależności pomiędzy tymi cechami. Natomiast w wielu polskich województwach i tylko kilku regionach $\mathrm{w}$ pozostałych krajach zaznacza się dodatnia zależność pomiędzy udziałem osób z wyższym wykształceniem w ogólnej liczbie pracujących a udziałem pracujących w przemyśle wysokich i średnich technologii w ogólnej liczbie pracujących. Może to wskazywać na istniejące procesy migracji wykształconej kadry z tych regionów oraz wskazywać na wciąż istniejący proces modernizacji polskiego przemysłu. 


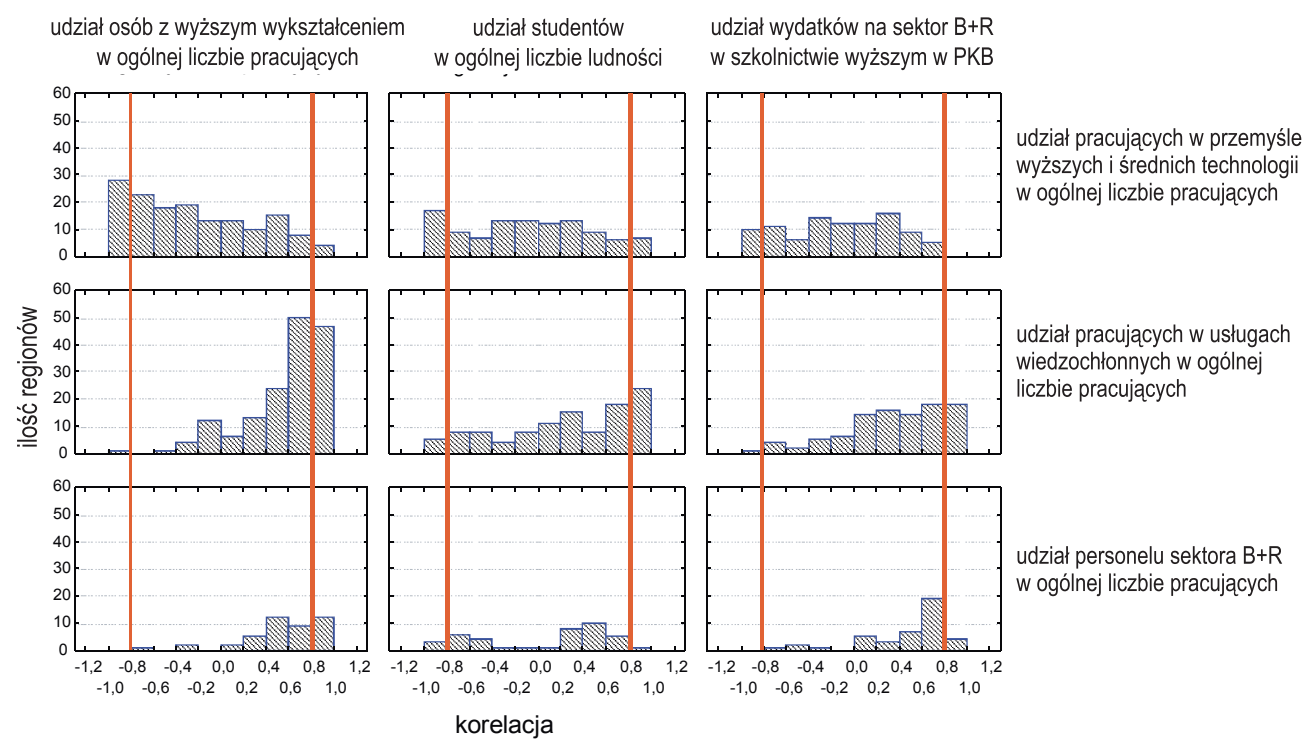

Ryc. 14. Korelacja wewnątrzregionalna pomiędzy analizowanymi wskaźnikami w latach 1995-2006

Źródło: opracowanie na podstawie własnych obliczeń

W świetle przedstawionych rozważań stwierdza się znaczne zróżnicowanie przestrzeni europejskiej w zakresie przedstawionych wskaźników. Wysoka pozycja konkurencyjna m.in. Szwajcarii, Danii, Szwecji, Finlandii i Niemiec wynika w dużym stopniu z ponoszonych wydatków na działalność $\mathrm{B}+\mathrm{R}$, $\mathrm{z}$ dobrze rozwiniętej współpracy pomiędzy nauką a przemysłem, z wysokiej jakości systemu szkolnictwa wyższego i w konsekwencji kapitału ludzkiego oraz zdolności absorpcji nowych technologii ${ }^{2}$. Generalnie w krajach o dużym udziale zatrudnionych w sektorze naukowo-technicznym w ogólnej liczbie pracujących występuje również wysoki poziom innowacyjności i konkurencyjności gospodarki (Węgrzyn 2008). Ponadto, jak wskazuje N. Daszkiewicz i in. (2008), pomiędzy wartością wskaźnika rozwoju społeczeństwa informacyjnego (Networked Readiness Index) określającego stopień wdrożenia i użycia nowoczesnych technologii informacyjnych i komunikacyjnych a poziomem konkurencyjności makroekonomicznej państw istnieje bardzo wysoka współzależność. Podobnie silna zależność zaznacza się pomiędzy poziomem rozwoju społeczeństwa informacyjnego (Information Society Index) a poziomem konkurencyjności makroekonomicznej, przy czym prawdopodobnie istnieją opóźnienia czasowe między kształtowaniem społeczeństwa informacyjnego a zwiększaniem poziomu makroekonomicznej konkurencyjności gospodarki. Na zwiększenie innowacyjności gospodarki i tempa rozwoju społeczno-gospodarczego różnej skali układów przestrzennych w znacznym stopniu wpływa jakość struktury zatrudnionych w poszczególnych sektorach gospodarki. W procesie kształtowania gospodarki opartej na wiedzy i społeczeństwa informacyjnego podstawowe znacznie ma jakość kapitału ludzkiego i zdolności adaptacyjne wykształconej siły roboczej do nowych uwarunkowań i wyzwań rozwoju cywilizacyjnego.

${ }^{2}$ http://www.weforum.org/documents/gcr0809/index.html - The Global Competitiveness Report 2008-2009, 2008 World Economic Forum. 


\section{Literatura}

Babiak J. red., 2008, Fundusze europejskie a innowacyjność polskiej gospodarki, Wydawnictwo Studio Emka, Warszawa.

Bal-Woźniak T., 2009, Infrastruktura systemu innowacyjnego jako czynnik transformacji struktur przemysłowych, [w:] Wpływ procesów globalizacji i integracji europejskiej na transformacje struktur przemystowych, red. Z. Zioło, T. Rachwał, Prace Komisji Geografii Przemysłu PTG, nr 12, Komisja Geografii Przemysłu PTG, Zakład Przedsiębiorczości i Gospodarki Przestrzennej, Instytut Geografii, Akademia Pedagogiczna im. Komisji Edukacji Narodowej w Krakowie, Warszawa-Kraków.

Borowiec M., 2008, Rola kapitatu ludzkiego w procesie podnoszenia konkurencyjności układów przestrzennych, [w:] Przekształcenia regionalnych struktur funkcjonalno-przestrzennych, red. D. Ilnicki, K. Janc, Rozprawy Naukowe Instytutu Geografii i Rozwoju Regionalnego Uniwersytetu Wrocławskiego 3, Instytut Geografii i Rozwoju Regionalnego Uniwersytetu Wrocławskiego, Wrocław.

Chojnicki Z., Czyż T., 2008, Gospodarka oparta na wiedzy w regionach metropolitalnych i aglomeracjach miejskich w Polsce, [w:] Rola polskich aglomeracji wobec wyzwań Strategii Lizbońskiej, red. T. Marszał, Studia, t. CXX, Tom wydany z okazji jubileuszu 50-lecia KPZK PAN, Komitet Przestrzennego Zagospodarowania Kraju Polska Akademia Nauk, Warszawa.

Daszkiewicz N., Korol T., Lachman E., Olczyk M., Starnawska M., Wolszczak-Derlacz J., 2008, Konkurencyjność. Poziom makro, mezo i mikro, WN PWN, Warszawa.

Goldberg I., Goddard G., Kuriakose S., 2008, Building Knowledge-Based Economy and Absorptive Capacity to Enhance Growth: The Role of Cross-Border Knowledge Flows in Europe and Central Asia (ECA), [w:] Knowledge-Based Economy as Factor of Competitiveness and Economy Growth, ed. M. Runiewicz-Wardyn, L. Koźmiński, Academy of Entrepreneurship and Management, Warszawa.

Hastie T., Tibshirani R., Friedman J., 2001, The elements of statistical learning. Data mining, inference, and prediction Canada: Springer.

Markowski T., 2008, Gospodarka bazująca na wiedzy (GOW) a wyzwania wobec zagospodarowania przestrzennego - konceptualizacja problemu, [w:] Rola polskich aglomeracji wobec wyzwań Strategii Lizbońskiej, red. T. Marszał, Studia, t. CXX, Tom wydany z okazji jubileuszu 50-lecia KPZK PAN, Komitet Przestrzennego Zagospodarowania Kraju Polska Akademia Nauk, Warszawa.

Okoń-Horodyńska E., 2000, Narodowy system innowacji w Polsce. W kierunku podejścia sieciowego, [w:] Proces dostosowania gospodarki polskiej do kryteriów członkowskich Unii Europejskiej, Wydawnictwo AE, MWES w Tarnowie, Kraków-Tarnów.

Reichel M., 2006, Potencjat innowacyjny Polski poludniowo-wschodniej w strukturach subregionalnych, Państwowa Wyższa Szkoła Zawodowa, Nowy Sącz.

Skrzypek E., 2007, Rola wiedzy we współczesnym zarzq̨dzaniu, [w:] Polskie firmy wobec globalizacji, red. A. Sitko-Lutek, PWN, Warszawa.

Węgrzyn G., 2008, Zatrudnieni w nauce i technice a innowacyjność gospodarki - dokument elektroniczny (http://www.instytut.info/IVkonf/referaty/Wegrzyn.pdf).

Zioło Z., 1985, Zastosowanie miernika syntetycznego w badaniu układów przestrzennych $w$ geografii przemystu, Seminarium KGP PTG, Łódź, Wydawnictwo Naukowe WSP w Krakowie. 


\section{Influence of human capital supplies on the creation of information society and the innovation of industrial structures}

In the transformation process from the industrial phase of civilizational development to the information phase, the economic base of different scales of spatial structures undergoes fundamental changes. The result of this process is the transformation of the job market. The number of workers in traditional industrial sectors decreases as the result of the development of new sectors connected with computer industry, which leads to workers' change in sectors of high technologies, both the industry and the services.

This article presents the analysis of differentiation of European space and the changes of chosen indicators related to the quality of human capital which determine the development of information society and the growth of economic innovation.

The authors of the article attempt to determine the relations between selected features, the dynamics of their development and the time correlation by means of a synthetic measure, related to the differentiation of intellectual potential and advanced economic technology in the analysed spatial structures (regions NUTS 2 and NUTS 1).

The research takes into account the influence of particular empirical indicators on the value of the synthetic measure. This allows creation of a kind of hierarchy of European space according to the analysed features and the synthetic values determining the differentiation of the quality of intellectual supplies and economic innovation.

dr Monika Borowiec

Uniwersytet Pedagogiczny im. Komisji Edukacji Narodowej w Krakowie Instytut Geografii

Zakład Przedsiębiorczości i Gospodarki Przestrzennej

e-mail: borowiec@ap.krakow.pl

dr Sławomir Dorocki

Uniwersytet Pedagogiczny im. Komisji Edukacji Narodowej w Krakowie Instytut Geografii

Zakład Przedsiębiorczości i Gospodarki Przestrzennej

e-mail: s.dorocki@ap.krakow.pl

dr Bartosz Jenner

Uniwersytet Jagielloński

Collegium Medicum

Katedra Toksykologii Klinicznej i Środowiskowej

e-mail: jennerb@poczta.fm 